\title{
HUMAN WORDS REACHING UP TO HEAVEN: THE THEME OF PRAYER IN THE DIALOGUE WITH C. S. LEWIS*
}

B A R B OR A ŠM EJ D OVÁ

\section{ABSTRACT}

The aim of the article is to investigate the theme of words in prayer. In the dialogue with the work of C. S. Lewis, we ask how it is possible to overcome the limits of our words in order to reach God and reality. At first, we point to several possible ways in which our language is limited. After that we focus on the process of 'gaining faces', which is the main concept of Lewis's novel Till We Have Faces but which can be complemented by the reading of his Great Divorce. This process is also demonstrated in the story of Jesus' encounter with the Samaritan woman. Last but not least, the article shows that the idea of overcoming the limits of words in our prayer cannot be separated from everyday life and that the principle of prayer should thus become the mode of Christian living.

Key words

Language; Prayer; C. S. Lewis; Till We Have Faces; Great Divorce; Samaritan woman

DOI: $10.14712 / 23363398.2019 .8$

\section{‘[H]}

uman speech is like a cracked kettle on which we tap crude rhythms for bears to dance to, while we long to make music that will melt the stars', ${ }^{1}$ notes Gustav Flaubert in his famous novel Madame Bovary. Although this quotation refers to the language of love, it summarises a wider human experience as we often struggle to express what we want to say, finding out that the words we use do not finally gain a corresponding response or the comprehension of the person we

* This article was supported by the project UNCE at Charles University no. 204052 and by the Charles University Grant Agency project no. 150316.

1 Gustav Flaubert, Madame Bovary (New York: Book of the Month Club, 1992), 216. 
communicate with. It seems as if our words are under a strange spell which makes them unable to reach the goal they are designed for. In theology, this experience necessarily enters into a reflection on the theme of prayer as it is, in its narrow sense, a conversation with God. The moment of prayer is a perfect example for testing the possibilities of our words since our communication counterpart cannot be blamed of miscomprehension or an inability to hear. The process of communication between two humans is significantly influenced by these limits; once we speak about God, each limit is on our side and God is prepared to overcome these limits by his grace if it does not go against our freedom, which he fully respects. It is thus the theme of human words in prayer which this article focuses on. Is there any possibility of overcoming the limitations of language or are our words condemned to roll in the mud in spite of our wish to lift them up to heaven? If it is possible to overcome these limits, how can we do it? The aim of this article is to investigate these questions with regard to the work of C. S. Lewis, for whom the ability of words for getting in touch with reality was of primary concern both in theory and in practice.

\section{Words and their Essential Limitations}

What is wrong with our words? Why are they unable to reach higher reality (or very often any reality) and why are they often spoken in vain? These are the questions Lewis had to ask as a literary scholar, Christian apologist, and ordinary believer, who raised his voice in prayer to God.

As a literary scholar he was deeply aware of the meaning shift which words undergo during a longer time period. His detailed handbook Studies in Words shows how some of the words which we take for granted today bore a significantly different meaning in the past. Analysing seemingly clear expressions like 'nature', 'free', 'simple', or 'life', C. S. Lewis warns his students to pay attention to the fact that they cannot interpret medieval and early modern poems in light of their present understanding of these expressions. His study is, nevertheless, eye-opening not only for those interested in old texts, as he testifies in the introduction to this book:

After hearing one chapter of this book when it was still a lecture, a man remarked to me 'You have made me afraid to say anything at all'. I know 
what he meant. Prolonged thought about the words which we ordinarily use to think with can produce a momentary aphasia. I think it is to be welcomed. It is well we should become aware of what we are doing when we speak, of the ancient, fragile, and (well used) immensely potent instruments that words are. ${ }^{2}$

Simply speaking, the detailed study of words leads to humility; it makes one aware of the boundaries which words impose and of the difficulty to overcome these limits at least partly.

As an apologist, C. S. Lewis pays attention to the fact that the words he uses to describe his religious experience do not have to mean the same for his readers and listeners. The above described difficulty speakers have to face is thus not relevant only for reading old texts, but it needs to be taken into account also when both communication partners are native speakers of the same language in the same time and place. In his apologetics, C. S. Lewis struggles to translate the ideas from his English to the English of common, uneducated people and unbelievers. Lewis describes this problem in his essay 'Christian Apologetics', where he also offers a short list of words inherent to religious vocabulary and adds a short explanation of how they are understood by common people:

ATONEMENT. Does not really exist in a spoken modern English, though it would be recognized as 'a religious word'. In so far as it conveys any meaning to the uneducated I think it means compensation. No one word will express to them what Christians mean by Atonement: you must paraphrase.

BEING. (noun) Never means merely 'entity' in popular speech. Often means what we should call a 'personal being' (e.g., a man said to me 'I believe in the Holy Ghost but I don't think He is a being').

CHARITY. Means (a) alms (b) a 'charitable organization' (c) much more rarely - indulgence (i.e., a 'charitable' attitude towards a man is conceived as one that denies or condones his sins, not as one that loves the sinner in spite of them). ${ }^{3}$

2 C. S. Lewis, Studies in Words (Cambridge: University Press, 2013), 6.

3 C. S. Lewis, Undeceptions: Essays on Theology and Ethics (London: Geoffrey Bles, 1971), 71 . 
According to Lewis's own experience, it is vital to adopt the attitude of kenosis towards unbelievers, less educated people, or towards children since it is the only way how to communicate the desired content. In his apologetics, Lewis does not presuppose that his readers should be familiar with religious language in order to be able to reach God. He chooses to be a translator who presents the Christian message in the language which is approachable and, not less importantly, enjoyable for most people.

Finally, Lewis struggles with the limitations given by words also in his own personal life of prayer, which undoubtedly is reflected in his own literary style. In this regard, he is aware of two kinds of danger: the human tendency to neglect the critical attitude towards the words of daily use and the tendency to hide concrete meaning by abstract words.

As concerns the first danger, Lewis acknowledges the traditional, unchallenged view that our speaking about God is always metaphorical, which means that God does not match our anthropocentric categories, and everything that we say about him is rather dissimilar than similar to who God is in reality. In addition to this, Lewis emphasises the fact that such limitations of human language are not only related to our speaking about God, but they concern human language as a whole. In other words, all human language is metaphorical, and the idea that we are able to speak literarily is an illusion, which makes our communication only more complicated. ${ }^{4}$ The lack of critical approach towards our own words in everyday experience can lead also to an uncritical approach in prayer and spiritual life. It is thus the advantage of each believer to realise that metaphoricity is contained in the simplest words, including, for instance, also the pronoun 'my'. This example is used in The Screwtape Letters, where the demon provides his diabolical advice:

We teach them not to notice the different senses of the possessive pronoun - the finely graded differences that run from 'my boots' through 'my dog', 'my servant', 'my wife', 'my father', 'my master' and 'my country', to 'my God'. They can be taught to reduce all these senses to that of 'my boots', the 'my' of ownership. Even in the nursery a child can be taught to mean by 'my Teddy-bear' not the old imagined recipient of affection to whom it

4 C. S. Lewis, Selected literary essays (London: Cambridge University Press, 2017), 251-265. It is worth mentioning that such an attitude is largely reflected by cognitive linguistics. See, for example, Vyvyan Evans and Melanie Green. Cognitive Linguistics: An Introduction (Edinburgh: University Press, 2006). 
stands in a special relation (for that is what the Enemy will teach them to mean if we are not careful) but 'the bear I can pull to pieces if I like'. And at the other end of the scale, we have taught men to say 'My God' in a sense not really very different from 'My boots', meaning 'The God on whom I have a claim for my distinguished services and whom I exploit from the pulpit - the God I have done a corner in'.

As Lewis demonstrates, the word 'my' is used for the description of various kinds of relations between a person and another person or a thing. The original (let us say non-metaphorical) meaning of 'my' determines something (or somebody) entirely belonging to me and being at my disposal. It is appropriate to thing like that about the articles of daily use, for instance. Even the expression 'my toy' has a different meaning as children learn to treat toys with more respect than a hat, for example. As it comes to other people or even God, we should pay special attention to the fact that, in these cases, the pronoun 'my' is linked with its original meaning only metaphorically. God is not mine in the same sense as a hat or shoes. To be aware of the metaphorical nature of language can thus prevent serious misinterpretations and misconceptions.

The words we use in prayer are the subject of a similar temptation to be taken literally rather than metaphorically. Cognitive linguistics teaches us that words do not carry meanings per se, but they are dependent on the way we contextualise them. A dictionary entry cannot be considered a sufficient tool for understanding a word as it is always determined by the context it appears in and presupposes a wider knowledge of the speaker. For instance, the linguist John R. Taylor names the word bachelor, which cannot be understood without the background knowledge of the culturally shaped notion of being married. In the same way, the word cup can be understood only against the cultural habit of drinking hot liquids. ${ }^{6}$ In prayer, we use words, which we contextualise according to our ordinary, human experience. Paradoxically, the same words are intended to aim at God, who escapes all our attempts to fix him in our categories. If, for example, the common pronoun 'my' can cause so much trouble, how complicated it is then

5 C. S. Lewis, The Srewtape Letters (New York: MacMillan Company, 1959), 109.

${ }_{6}$ John R. Taylor, Linguistic Categorization (Oxford: University Press, 2003), 84. 
to distinguish between respective meanings of the word 'love'. Is there any way to escape this trap?

Secondly, Lewis underlines that ' $[\mathrm{h}]$ uman intellect is incurably abstract. Pure mathematics is the type of successful thought. Yet the only realities we experience are concrete - this pain, this pleasure, this dog, this man. ${ }^{7}$ Our prayer can thus become trapped in the abstract very easily, especially if our intellect is used to constructing abstract ideas. However, the mind of the person who stands before God should not operate in the abstract or hypothetical mode: 'do not worry about tomorrow, for tomorrow will worry about itself. Each day has enough trouble of its own' (Matt. 6:34). Similarly, the Lord's Prayer teaches us to say 'give us this day our daily bread', that is, that only the concrete present moment is relevant; tomorrow's events and abstract ideas become the subject of a prayer as soon as they gain their concrete form as man can always remain in God's transformative presence. In the same line, when Lewis thinks about the prayer as worship or adoration, his imagination is directed towards the most concrete object:

[t]hat cushiony moss, that coldness and sound and dancing light were no doubt very minor blessings compared with 'the means of grace and the hope of glory.' But then they were manifest. So far as they were concerned, sight had replaced faith. They were not the hope of glory, they were exposition of the glory itself. ${ }^{8}$

Nevertheless, as we can see, even the simplest words can be misleading. Although our words are as concrete as possible, we can never be sure that they will touch reality as we do not know to what extent our minds are open to reality; how can man stand before God if his view is full of biases? How can we talk with God if we wear a mask which prevents our words from reaching further than to our own self? How can we talk to God and how can we talk meaningfully at all till we have faces?

Lewis, Undeceptions, 41.

C. S. Lewis, Letters to Malcolm: Chiefly on Prayer (New York: Mariner Books, 2012), 88-89. 


\section{Till We Have Faces}

In his work, Lewis often draws a distinction between the full, tangible, and vivid reality and the one which is shadowy, misty, and indefinite. The former moves in the logic of grace; the latter refers to the life of sin. Most transparently, it is described in his book The Great Divorce. The reality of heaven is depicted as bright, fresh, and colourful with singing birds, blooming flowers, and dancing leaves. In contrast, the hell of this narrative is a vast, ghostly city at dusk with people moving further and further away from their neighbours. In both worlds, the inhabitants of hell experience pain. In hell, it is a pain of depreciated egoists, whose greedy selfishness can never reach satisfaction. When the same characters are confronted with the concreteness of heaven, they experience a different kind of pain: the pain of reality. They are too shadowy, their senses are too weak, and their minds are too shaky so that each contact with anything real causes unbearable suffering. What is more, they are unable to use real objects since reality is too hard and tough for them:

I bent down and tried to pluck a daisy which was growing at my feet. The stalk wouldn't break. I tried to twist it, but it wouldn't twist. I tugged till the sweat stood out on my forehead and I had lost most of the skin off my hands. The little flower was hard, not like wood or even like iron, but like diamond. ${ }^{9}$

The visible reality of Lewis's allegorical narrative is, however, mainly the demonstration of what is happening inside the minds of the characters, which is reflected in the language they use. The language of the inhabitants of heaven is straightforward, meaningful, and resonant. In their speech, there is no fear, no tendency to hide anything, and no hint of false compassion. Contrastingly, the speech of those coming from hell is full of self-pity, selfishness, and self-deception. For example, the Lady living in heaven says to her small, crooked companion: 'What needs could I have ... now that I have all? I am full now, not empty. I am in Love Himself, not lonely. Strong, not weak. You shall be the same. Come and see. ${ }^{10}$ However, the ghost of a man called the Tragedian

9 C. S. Lewis, The Great Divorce (London: Collins, 2012), 21.

10 Lewis, The Great Divorce, 126. 
responds to this invitation in these words: 'She needs me no more - no more. ... [W]ould to God I had seen her lying dead at my feet before I heard those words. Lying dead at my feet.'11

For those living in the grace of God, reality is not only acceptable, but they can live in it, use it, and feel it. Their words are articulate, loud, and clear, but it is not because they would be capable of overcoming the above described limits. Their words become resonant because they stop being the first words which are pronounced. The words which are full of selfishness are absolutely autonomous; they do not accept any limitation, any modification, or shaping. They follow the famous declaration from Milton's Paradise Lost: 'Better to reign in Hell than serve in Heaven.' In this case, the limitations of words described in the first chapter are fatal. Their inability to be in touch with reality cannot be overcome; the tower of Babel will never be finished.

In contrast, those who decide to take off their masks and veils and let themselves be transformed by God perceive all their words as a response to the eternal Word, which was in the beginning (John 1:1) and which will never pass away (Matt 24:35). Regarding this theme, the Swiss mystic Adrienne von Speyr says:

Every saint runs up against this limit; every disciple and everyone who genuinely prays must meet up with his inability even in those moments when he is not preoccupied with his own concerns, because the word is so strong within him that it graciously, so to say, wipes away his human limitations. The word is so alive that it can carry in itself as living what is dead in the sinner. ${ }^{12}$

Simply speaking, the limits given by our human condition can be overcome only when we move within the space of Jesus Christ, the Word made flesh.

Let us, for instance, remember the story of Jesus meeting the Samaritan woman. He says to her, 'If you knew the gift of God and who it is that asks you for a drink, you would have asked him and he would have given you living water' (John 4:10). The response of the woman is very simple, following common human logic: 'you have nothing to draw with and the well is deep' (John 4:11). Jesus does not tend to be

11 Lewis, The Great Divorce, 126.

12 Adrienne von Speyr, Man Before God (San Francisco: Ignatius Press, 2009), 66. 
tied by this logic. There is no tendency to explain to the woman that he is talking in different terms and that what she says actually does not make sense in relation to the idea of water he has in mind. He simply continues: 'Everyone who drinks this water will be thirsty again, but whoever drinks the water I give them will never thirst' (John 4:13-14). The woman is still not able to give up her limited perspective: 'Sir, give me this water so that I won't get thirsty and have to keep coming here to draw water' (John 4:15). Without being aware of it, the woman is actually praying; she asks Jesus for something which transcends her thinking. The way she uses the word water is limited, closed, and imprecise. Yet, the Lord accepts these terms; what is more, he slowly leads the woman from her logic to his logic when standing at a simple, material well and asking for ordinary water to drink.

Jesus' answer to this prayer goes, however, in an unexpected direction: 'Go, call your husband and come back' (John 4:16). Instead of asking for the water Jesus promised before and instead of trying to pretend that she is worthy of such a gift as she is a respectable married women, she answers, 'I have no husband' (John 4:17). The Lord replies, 'You are right when you say you have no husband. The fact is, you have had five husbands, and the man you now have is not your husband. What you have just said is quite true' (John 4:17-18). That moment is essential because it shows that Jesus does not speak to a mask or to a veiled face. The woman is standing before him, honest, fragile, and sincere. Her words about water were limited, from the point of view of educated theologians even childlike; yet, the Lord decides to lift them up to the sphere into which no education can lead us. The prayer of 'give me this water so that I won't get thirsty' is heard as Jesus discloses his identity and invites the woman to his companionship by saying, 'I, the one speaking to you - I am he' (John 4:26).

Similarly, in prayer, we should not suppose that our words are just ours. The words should be sacrificed, given, and open to any interpretation which God will like. The answers to our petitions might be unexpected. Prayer is no substitute for a magic wishing apple. The limits of our words can be overcome, but the sphere they reach goes beyond our comprehension and beyond our control. It is a sphere of absolute blindness, which can be endured only thanks to the infused virtues of faith, hope, and love.

The transformation from self-deception towards this kind of spiritual openness is described in Lewis's novel Till We Have Faces. Orual, the 
heroine of the story, is a strong queen who is used to having everything under her control. The world is organised according to her own wishes. Once someone around her wants to escape her control and selfish love, she has the authority to prevent them from doing so. Orual is able to rule like this all the time, yet with one exception - her beloved sister Psyche, who is sacrificed to the God of the Mountain. Orual is prepared to rescue her or to mourn and pity her. The situation escapes Orual's control once she finds out that Psyche does not need to be rescued, but that she is happily married to the unknown and unseen god. That is why she forces Psyche to go against her husband's prohibition and look at his face in the light of a lamp. Orual hopes to have the opportunity to comfort desperate Psyche and prove that she is the true friend. Nevertheless, after doing so, Psyche loses her happiness, and Orual cannot see her again. Orual cries out to the gods, but they remain silent. ${ }^{13}$ Only after having discovered her selfishness, she is able to see the story in its real meaning. Through this painful process, her heart is purified and able to face God directly: 'I know now, Lord, why you utter no answer. You are yourself the answer. Before your face questions die away. ${ }^{14}$ All previous words of her self-defense as well as her accusations of gods were spoken in vain. Once she surrendered to the mystery and stopped fighting for her rights, she became able to listen, her words gained meaning and, finally, she was able to enter a space where words were not necessary any more - a space beyond human words.

\section{Prayer as a Mode of Living}

From the abovementioned ideas, we can infer that prayer cannot be easily limited to a single moment of repeating learned words before going to sleep or before starting our meals. Prayer, if it becomes genuine, enters into all aspects of life; in other words, prayer becomes the mode of living. Openness towards God's will accompanied with the ability to overcome the temptation to have everything under control is not

\footnotetext{
13 More precisely, Orual formulates the accusation of the gods, which forms the first part of the novel. For a summary of this accusation see Doris T. Myers, Bareface: A Guide to C. S. Lewis's Last Novel (University of Missouri Press, 2004), 113.

14 C. S. Lewis, Till We Have Faces: A Myth Retold (Orlando: Harcourt, 1956), 308. See also Peter J. Schakel, Reason and Imagination in C. S. Lewis: A Study of Till We Have Faces (Grand Rapids: Eerdmans, 1984), 69-86.
} 
only the basic presupposition of good prayer, but it concerns everyday human action.

Our actions should be like our words in prayer. They should be aimed at God even though we do not see their immediate benefits and even though they might be foolish and illogical from the point of view of the world. The word of God is a gift for us; however, this gift is often wasted and often left without any response. In order to be similar to God, we should not be afraid of wasting our words and energy, and struggle every day in spite of the fact that no one can see it, no one might appreciate us, or we receive no response. In the logic of God, the smile without reaction, the gift without gratefulness, and the help without profit are much more worthy than their more visible and graspable counterparts:

So when you give to the needy, do not announce it with trumpets, as the hypocrites do in the synagogues and on the streets, to be honoured by others. Truly I tell you, they have received their reward in full. But when you give to the needy, do not let your left hand know what your right hand is doing, so that your giving may be in secret (Matt 6:2-4).

When we pray, we do not know in which way the Lord transfers our words; in the same way, we should not care what God uses our action for. Only such words and such deeds can touch reality because they are open to be transformed to do so. God is the Word; man is not a word but a response. If our words and deeds were the first, we could become disappointed and discouraged if they did not receive a real response; if we change our perspective and perceive our words and deeds as a response to the word of God, who invites us with the risk of being refused, we can do the same with freedom and happiness. Then we can receive an unexpected blessing, as Lewis formulates in his Letters to Malcolm:

I am beginning to feel that we need a preliminary act of submission not only towards possible future afflictions but also towards possible future blessings. I know it sounds fantastic; but think it over. It seems to me that we often, almost sulkily, reject the good that God offers us because at that moment we expected some other good. ${ }^{15}$

15 C. S. Lewis, Letters to Malcolm, 26. 
Although we have now elaborated Lewis's views a little beyond the scope of his work, in his essay 'Christianity and Literature' he follows a very similar direction. He focuses his attention to the problem of whether art is the expression of the author's personality or if it should be a mimesis of outer reality. While spontaneity, freedom from rules, and creativity are important values of modern literary criticism, C. S. Lewis highlights that the work of Christian artists should not be the expression of their genuine creativeness, but it should reflect higher beauty and higher reality. The task of Christian authors is not to express themselves but to imitate God. For our discussion, it is important that Lewis supports this argument by his study of the New Testament, which does not talk about literature but deals with the problem of whether the life of a person should be the expression of his or her personality or if it has a different goal.

Referring to the theology of St Paul as well as the Fourth Gospel, Lewis arrives at the following conclusion: “[o]riginality” in the New Testament is quite plainly the prerogative of God alone; even within the triune God it seems to be confined to the Father.' ${ }^{16}$ He continues in the line of St Augustine's thinking and adds that 'pride does not only go before a fall but is a fall - a fall of the creature's attention from what is better, God, to what is worse, itself'. ${ }^{17}$ When he applies this principle to literature, he shows that this attitude leads to greater freedom since Christian authors are not limited by their quest for original expression and for acceptance by critics.

If we apply this principle to Christian life in general, Scripture asks us to give up our struggle to become 'ourselves' as our task is to surrender and imitate Jesus Christ. The dynamics of expression and mimesis is not, however, that simple. At first, Lewis refuses expression in favour of mimesis, but it simultaneously means that we should not imitate anyone other than the Son of God, the Word, according to whom everything was created and who is the principle of the whole universe. Nevertheless, the movement is not complete. Once we turn our perspective outside of ourselves, our perspective is transformed even if it still remains ours. Thus, it can be assumed that we are more 'ourselves' than we were before. The reason is that relationship is a necessary element of human beings, and paradoxically, when we turn ourselves

${ }_{16}$ C. S. Lewis, Christian Reflections (London: HarperColllins, 1980), 8.

17 C. S. Lewis, Christian Reflections, 9. 
towards someone else, we do not lose but we gain. Thanks to the grace of God, we can overcome not only the limits of our words in prayer but also the limits of our human existence in general. In this way, we can escape our shadowy and fragile way of being and enter into the realm of the real.

\section{Conclusion}

In this article we have tried to answer the question of whether and how our words are able to participate in a higher reality when we pray. Thanks to our dialogue with the work of C. S. Lewis, we were able to describe the basic restrictions which our language has. As a literary scholar and apologist, he proved to be a skilful translator not only from one language to another but also from his English to the English of his readers and listeners. Nevertheless, being aware of the difficulties connected with language, he approaches his own language with humility and does not regard himself as being always in a superior position. In the face of God's mystery, he finds out that it is not only him who translates, but that he is also in need of having his own words translated, as he expresses through the mouth of his autobiographical character John in The Pilgrim's Regress:

And all men are idolators, crying unheard

To a deaf idol, if Thou take them at their word.

Take not, oh Lord, our literal sense. Lord, in Thy great,

Unbroken speech our limping metaphor translate. ${ }^{18}$

The fact that God is willing to work as a translator of our speech was demonstrated in Jesus' dialogue with the Samaritan woman. The same example, however, showed that what Lord requires is not the exactness of expression and conceptual precision but an open heart without any mask or veil. That is why we should struggle to avoid the temptation to create God in our own image, but we should be open to become the image of God.

This is what C. S. Lewis teaches his readers either explicitly or implicitly. The theme of prayer as reflected through the perspective of

18 C. S. Lewis, The Pilgrim's Regress: An Allegorical Apology for Christianity, Reason and Romanticism (Glasgow: William Collins Sons, 1983), 183. 
language shows that Lewis's legacy is very profound and up to date. His ideas about language can be discussed in relation to contemporary reflections on language, and his perspective on prayer is able to find its echo in the writings of great Christian mystics. For instance, Adrienne von Speyr underlines that words in prayer 'live from the Son's substance, ... filling them with life above and beyond their earthly capacity and temporality. Their limitations are suspended because each word is freighted with a heavenly content which, from the outset, directs it towards God.' ${ }^{19}$ C. S. Lewis's ideas on prayer are directly in line with such view. This example shows that C. S. Lewis can be regarded not only as an English literature scholar, apologists, and populariser of Christianity; he is also an inspiring spiritual author, who is able to present his profound ideas in an approachable and concrete way.

Catholic Theological Faculty, Charles University Thákurova 3 16000 Praha 6 E-mail: smejdova@ktf.cuni.cz

19 Adrienne von Speyr, The World of Prayer (San Francisco: Ignatius Press, 1985), 135. 